DOI https://doi.org/10.18551/rjoas.2017-11.30

\title{
ANALYSIS OF MIGRANTS' COMPETITIVENESS IN INDONESIA
}

\author{
Harlen*, Pailis Eka Armas \\ Faculty of Economics, University of Riau, Indonesia \\ Karneli Okta \\ Faculty of Social and Political Sciences, University of Riau, Indonesia \\ *E-mail: harlen.ho@gmail.com
}

\begin{abstract}
This study was conducted to investigate and analyze the influence of skills toward migrants' competitiveness and the influence of wisdom toward migrants' competitiveness in Pekanbaru, the capital city of Riau Province, Indonesia. This study employed a quantitative approach in the form of survey. There were 125 migrants who participated in this study who were chosen using quota sampling technique based on the classification of migrants' activities. The first finding shows that there is a significant influence between migrants' skills and their competitiveness. Secondly, migrants' wisdom has certain positive yet insignificant influence toward their competitiveness. The results of this study also show that migrants' competitiveness has been satisfying. Migrants are also known to have strong basic characteristics to achieve certain target or to reach their success.
\end{abstract}

\section{KEY WORDS}

Migrants, motivation, competitiveness, skills, wisdom.

City is an ecosystem of life which also becomes the machine of life for cities provide various source of living. Thus, this machine is expected to be effective and efficient in serving the people. Cities are a set of functional arrangement in which houses, jobs, shopping centers, and services are clearly separated. This makes sub urban areas which were considered as recreational spots now have been used as expanded residential area. Pekanbaru is one of big cities in Indonesia which is located in a strategic location. Pekanbaru has 12 sub-districts and 58 villages in approximately $632.26 \mathrm{~km}^{2}$ area. $24 \%$ of the area has been used as residential area (around $75 \%$ of this area), government offices, trading area, educational area, industrial area, military area, airports, and so on. Around $76 \%$ of the city area are protected forest, farms, forest, etc. Pekanbaru needs larger city area since the number of the people is highly increasing. This has led the city to remain narrow available area. The high population is dominated by the high number of migrants in Pekanbaru.

Starting from the implementation of local autonomy as stated in the Act Number 32 of 2004 on local governance, local governments are given chances to develop and raise their own economy. Hence, small cities are well developing and attract job seekers to migrate there. The same phenomena also occurs in Pekanbaru which as much as $60.8 \%$ of the population are migrants and Pekanbaru has reached up to $9.2 \%$ of economic growth every year (Dinas Kependudukan dan Catatan Sipil, 2010). Migrants refer to residents who live in Pekanbaru in a certain length of time and who have fulfilled conditions as migrants in the form of Kartu ljin Pendatang (KIP) which is an identity card for legal migrants given by the municipal government issued by the Dinas Kependudukan dan Catatan Sipil (Distardukcapil), according to Local Act No.5 of 2008.

Subagyo (2002) stated that environmental damages are triggered by two factors; natural factors and human made factors. Those factors are highly correlated to each other since environmental damages caused by natural events might appear as the result of human destructive activities. Residents of a city hold the responsibility to keep the environment healthy. Higher population in an ecosystem also becomes another problem. The correlation between population density and the quality of the environment is quite strong, for instances; 
the lower the quality air and water, the higher the population since industries demand more workers to run their business. It is explained that the increase in the population leads to the higher need of jobs along with the necessities of other production factors and how well the technologies provide good output. As the implication, the increase in the population decrease the quality of the environment through the relationship between the number of population and the availability of workers and the relationship between the availability of workers and production capacity and economic problems (Suparmoko, 2008).

The phenomena of people coming into a city is called immigration and immigration is triggered by certain causes and has certain effects toward the environment of a city. There are various factors that motivate the people to move out to a city as explained by Lee (1995) in which it is stated that migration volume goes equally with environmental variety. There are positive factors, negative factors and neutral factors of both previous area and the target city. According to Lee, Todaro, Titus (in Mantra, 2003), economic motive is the strongest factor that motivates a person to migrate. This problem is triggered by imbalanced economic development of the suburban area and the urban area. Todaro (2002) considered this economic motive a rational reason to migrate.

Noris (in Mantra, 2000) added three components into Lee's model of migration which are; re-migration, obstacles and forced migration. Noris explained that the factors from the suburban area are the most important ones. Jones also mentioned that modernization does not simply attract people from other area, yet it might also motivate natives to move out of a city due to the advancement of education system, transportation and communication. Advancement of technology, transportation and communication has made migration easier.

Other theory has been proposed by Lewis (1954) on the migration process of workers from suburban area to urban area which was later formulated and expanded by Fei and Ranis (1964) as a general theory on national development of surplus workers in third world countries. The main focus of this model is the process of workers; migration and job opportunity in the modern sectors.

Based on this explanation, it is obvious that cities are considered as a machine to make living. Therefore, the existence of a city needs to be maintained. This study focuses on the migrants who tend to have high motivation to migrate due to the attractiveness of a city, thrust from the place of origin, personal factors and obstacles in the form of government's rules. The research question of this study is related to both simultaneous and partial influences of skills and wisdom as the capital of migrants' competitiveness in Pekanbaru.

\section{LITERATURE REVIEW}

In a theory of development by Goutlet (in Todaro, 2002), development refers to any exhaustive changes including an attempt to conform the whole social system to fit humans' basic necessities and different expectations of individuals and social group within the system, and the need to move from an unfavorable condition to a better and favorable condition which is more humane in the terms of materials and spirituals. Development should consider the factors of humanity that can be reached by these three basic necessities: (1) life needs which refers to the fulfillment of human welfare that is often reflected by per-capita income, (2) freedom from slavery and freedom to choose which refer to the needs of education, health and general quality of life and (3) self esteem and self respect.

Based on the theory of development by Lewis (in Suparmoko, 2008), development is measured through the economic matters. Retarded state of economy is identified by two sectors: (1) traditional sectors; ove population sub-urbans shown by marginal productivity close to zero or surplus of workers caused by the shifting of agriculture workers to industrial workers without any loss of output; and (2) industries in cities which have higher productivity attract workers from the subsystem sectors (sub-urban).

Furthermore, Suparmoko (2008) explained that the relationship between economic growth and the availability of natural resources is not the same as the relationship between economic growth and the availability of resources used in a production process. The faster the economic growth, more natural resources are needed for production process which 
eventually decreases the availability of natural resources. Therefore, the acceleration of economic development in the developing countries demands higher amount of natural resources taken from the earth which decreases the volume of the natural resources. There is a positive correlation between the quality of the quality of resources and economic growth, yet there is also a negative correlation between economic growth and the amount of natural resources available in the earth.

Migrants are people who migrate from one place to another place. Mattulada (1994) stated that migration is human movement as individuals or as a group from one place to another place. This process is followed by the transmission of cultural products, customs, minds, and skills exchange among individuals, groups or from a society to societies. From the ecological point of view, human accept physical environment, society, and culture of where they live. When the condition is stable, there will be a balance of daily necessities availability. In this condition, there will be an equilibrium of the number of population and the resources need, balanced state of mortality and nativity in both short term and long term. If any changes occur in this balanced biotic condition, there will be a change of relationship among human, environment and food stock. Adjustments should be made to follow the changes including the change of the relationship between human and their need of food.

Some concepts of migration theories are presented as follows.

Lee's Push-Pull Theory (1995). According to Lee (1995), migration in a broader scope means a permanent and semi-permanent changes of one's place of living. There is no limit of either distance or ones' intention to migrate (forced or voluntarily). In the other words, migration is a movement of human from a place to stay in another place. Meanwhile, migrants refers to the individuals who do migration. Regardless of how far the distance or the condition, migration always involves the place of origin, target place, and obstacles. Distance is one of the migration factors.

A place has some factors that make the residents stay in the place or even attract other people to live in that place. Some factors have similar effects toward some people, yet there are also some factors which give different effect toward some people. Positive and negative factors are always found by migrants and future migrants related to their attitude toward the condition of the place of origin and the target place. The positive factor of the place of origin is in the form of the drive experienced by a person to leave the place. Whilst, the negative factor of the place of origin obstructs a person from leaving out the place. Similarly, negative factors of the target place include any factors that are considered unfavorable, which prevents people from coming and living in that place. Ones might have positive, negative or neutral views toward certain factors. It depends on the personal condition of a person which can be influenced by education, experience, necessities and personalities, Ones also might have different perception on the obstacles of migration. Migration obstacles include distance, travel cost, immigration procedures, and the number of the family members.

Zipl's Theory of Gravity. Zipl has proposed a classic model of gravity related to migration. It is stated that the number of migrants in two places goes directly proportional with the multiplication results of the number of the population and it goes inversely proportional with the closest distance of transportation between the two places. Lowry and Rogers have modified the Zipl formula by adding up the per-capita income, unemployment, and the workforce into the measurement. This formula is used to count the number of migrants of two places. However, this formula does not include information of the target place and the existence of families there as important factors. Some theories related to migration are: 1) the farther the distance, the lower the number of migrants. This theory is known as distance-decay theory. 2) ideal migration raises an exchange in the form of reverse flow. 3) gaps between urban area and sub-urban area also trigger migration. 4) women tend to migrate to nearby paces and 5) the advancement of technology increases the intensity of migration and 6) economic matters are the main motives of migration.

Jones' Theory of Migration (2009). Jones (2009) described migration as a process of modernization. Jones also mentioned that modernization does not only attract people from outskirt area to come but it also motivates the natives to migrate as the education, 
transportation and communication are advanced. Advancement of technology, transportation and communication make migration easier.

Lewis's (1954) and Fei and Ranis' (1968) Theory. The pattern of a city development gives an implicit consideration of workers movement from sub-urban area to urban area. This Lewis's (1954) and Fei and Ranis' (1968) theory has been accepted as a general model applied in the third world countries that experience the surplus of workers. In this model, economy consists of sub-urban subsystem sector which is identified by the surplus of workers while the modern industrial sectors in urban areas is seen from the high production capacity.

Todaro's Migration Theory (1996). Todaro (1996) assumed that the decision to migrate is a rational economic phenomena. Even though cities have high number of unemployment, Todaro believed that ones always have expectation to earn higher income from cities than wages from agriculture sector. As implication massive number of people migrate in order to earn higher income. However, the fact does not always match the expectation.

There are four essential characteristics of Todaro's model of migration theory (1996) which are: 1) migration is initiated by rational economic consideration of income and outcome; 2 ) the decision to migrate depends on the real expected wages between urban and sub-urban instead of the actual wages between urban and sub-urban; 3) the probability to get a job in a city is reversely proportional to the number of unemployment; 4) the volume of migration is higher than the availability of jobs in cities.

Migrants are those who migrate. Mattulada (1994) mentioned that migration is a movement of individuals and groups from a place to another place. This process is followed by the transmission of cultural products, customs, minds and skills from individuals, from groups to groups and from societies to societies. Seen from the ecology point of view, one accepts the conditions that they face including the physical environment, other individuals and the culture of where she/he lives.

Wijaya (2007) defined competitiveness as an ability to achieve better result. Whilst, Mitriani (in Preffer, 2002) stated that competitiveness is a basic characteristic that is related to the effectiveness and achievement of how ones' perform their jobs.

Ubaedy (2009) stated that competitiveness is the same as competence which refers to the ability or readiness. Compete, competition, and competitive mean the act to create something special and better. Soetjipto (2007) explained that competitiveness is something that is appealing and unique that can be used to consistently win over other competitors. According to Wljaya and Mitrani in Prefer and Ubaedy and Soetjipto, competitiveness is defined as the basic characteristics of individuals that can be used to achieve success, achievement or to reach goals.

Indicators of competitiveness according to Khairul Muluk (2008) include the dimension of competitiveness, competition of efficiency, productivity, quality, adaptation and innovation. The framework of this study is related to migrants' motivation (attractiveness, driving force, obstacles and competitiveness as independent variables and their effects for migrants in Pekanbaru as the dependent variable.

\section{METHODS OF RESEARCH}

This study was conducted in Pekanbaru city that has 12 sub-districts. The researcher employed a survey technique to collect the data of this study. The population includes 130,805 head of family migrants in Pekanbaru who had various jobs and were classified based on their length of stay in Pekanbaru. The target population of this study are migrants who had been staying in Pekanbaru for less than one year, migrants who possess migrants' identity card of 2012, and migrants who had been staying for one to five years and more than five years.

The sample of this study included some migrants who owned migrants' identity card $(K I P)$. In order to determine the number of the sample used in this study, researchers set level of representativeness at $95 \%$ toward 130,805 population. Samples included migrants who had been living in Pekanbaru for more than five years. There were 10 indicators. 
Accidental sampling technique was employed to choose 125 samples. Meanwhile, the data collection was conducted using documentary study and questionnaires. The data were then analyzed using SEM to measure the contribution of the coefficient in each diagram path of causal relationship of the variables $\mathrm{X} 1$ and $\mathrm{X} 2$ toward the variable $\mathrm{Y}$. This scheme was the base to measure the equation structure model (SEM) which was then calculated using AMOS.

\section{RESULTS OF STUDY}

Based on the determination of model value, the variables of the model measurement in this stage were classified into exogenous variables and endogenous variables. Exogenous variables refer to the skills and wisdom. Whereas, endogenous variable of this study refers to the competitiveness. The result of the SEM analysis in this stage can be seen in Figure 1.

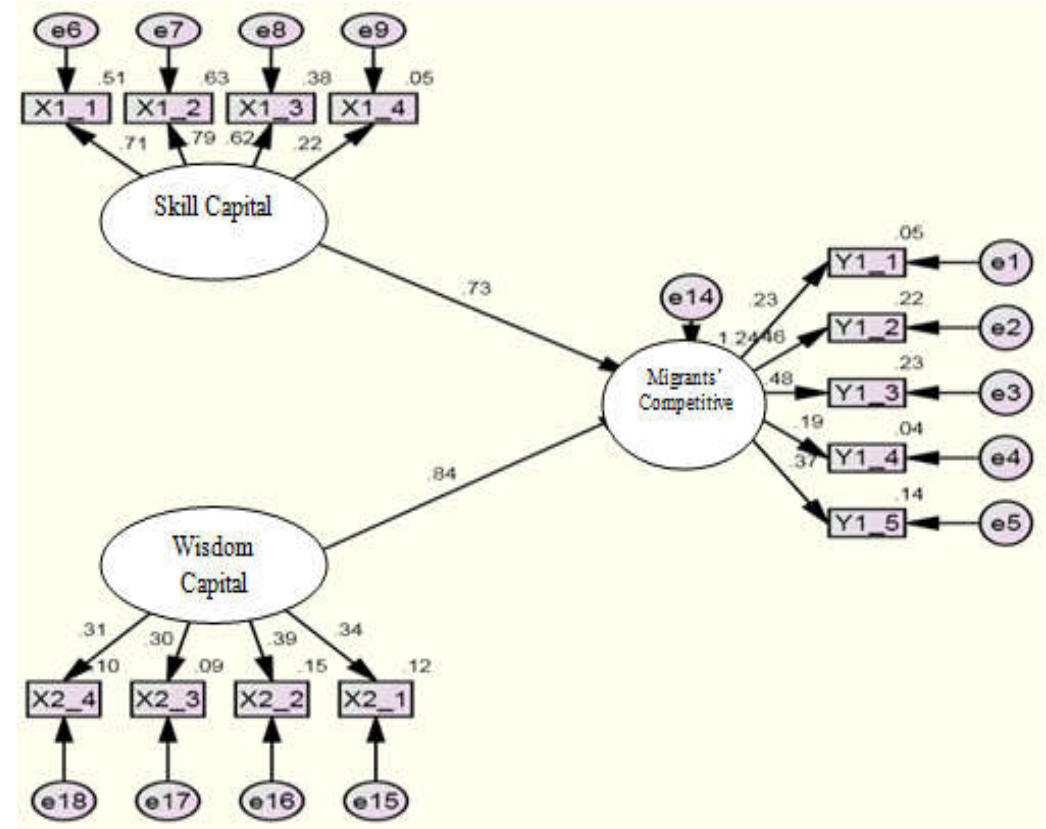

Figure 1 - Results of SEM Analysis

The hypothesis testing on the structural model has direct relationship with the result of the regression coefficient measurement of each path. Hypothesis testing was done by measuring the level of significance and the probability value. If the probability value is lesser or equal to 0.05 , the correlation is significant (Boge, 2009). The regression coefficient of each path is shown in Table 1.

Table 1 - Results of Variable Measurement

\begin{tabular}{|c|c|c|c|c|c|}
\hline $\mathrm{n} / \mathrm{n}$ & Estimate & S.E. & C.R. & P & Label \\
\hline Skill Capital & .192 & .049 & 3.956 & ${ }^{* * *}$ & par_13 \\
\hline Wisdom Capital & .041 & .080 & .517 & .605 & par_14 \\
\hline $\mathrm{X} 1 \_1$ & .184 & .034 & 5.393 & ${ }^{* * *}$ & par_21 \\
\hline $\mathrm{X} 1 \_2$ & .150 & .038 & 3.977 & ${ }^{* * *}$ & par_22 \\
\hline $\mathrm{X} 1 \_3$ & .323 & .051 & 6.361 & ${ }^{* * *}$ & par_23 \\
\hline $\mathrm{X} 1 \_4$ & .298 & .039 & 7.736 & ${ }^{* * *}$ & par_24 \\
\hline $\mathrm{X} 2 \_1$ & .315 & .087 & 3.642 & ${ }^{* * *}$ & par_25 \\
\hline $\mathrm{X} 2 \_2$ & .136 & .035 & 3.918 & ${ }^{* * *}$ & par_26 \\
\hline $\mathrm{X} 2 \_3$ & .257 & .051 & 5.015 & ${ }^{* * *}$ & par_27 \\
\hline $\mathrm{X} 2 \_4$ & .306 & .076 & 4.030 & ${ }^{* * *}$ & par_28 \\
\hline
\end{tabular}

Source: Analyzed Data, 2016. 
Table 2 - Result of the Structural Model Hypothesis Testing

\begin{tabular}{|c|c|c|c|c|c|c|}
\hline Hypothesis & Estimate & S.E. & C.R. & $P$ & Label & Note \\
\hline Skill Capital $\rightarrow$ Migrants' competitiveness & .210 & .107 & 1.957 & .050 & par_8 & Significant \\
\hline Wisdom Capital $\rightarrow$ Migrants' competitiveness & .521 & .829 & .628 & .530 & par_12 & Insignificant \\
\hline
\end{tabular}

Table 1 and 2 imply the explanation of the hypothesis as follows.

Testing of Hypothesis 1. Migrants' skill is found to have a significant influence toward migrants' competitiveness in Pekanbaru at the regression coefficient of 0,210 , CR of 1,957 and level of significance of 0,05 . Therefore, Ho is rejected. The result of this study shows that skill has a positive and significant influence toward migrants' competitiveness in Pekanbaru.

From the measurement of each indicator, the influence of each indicator toward migrants' competitiveness is explained as follows.

1. The influence of knowledge toward migrants' competitivenss. The influence of knowledge toward competitiveness is found at 0.184 , and CR at 5.393 with the level of significance at 0.000 . It implies that knowledge has a positie and significant influence towad migrants' competitiveness.

2. The influence of education toward migrants' competitiveness. The influence of education toward migrants' competitiveness is found at $0.150, \mathrm{CR}$ at 3.977 and level of significance at 0.000 . Thus, education has a positive and significant influence toward migrants' competitiveness.

3. The influence of skills toward migrants' competitiveness. The influence of skills toward competitiveness is found at $0.323, \mathrm{CR}$ at 6.361 and level of significance at 0.000 . This result shows that skills have a positive and significant influence toward migrants' competitiveness.

4. The influence of experience toward migrants' competitiveness. The influence of experience toward migrants' competitiveness is found at $0.298, C R$ at 7.736 and level of significance at 0.000 . This indicates that experience has a positive and significant influence toward migrants' competitiveness. Out of those four indicators, migrants' skill appears to have the strongest influence toward migrants' competitiveness, followed by expeience. Whilst, migrants' education shows the lowest influence.

Testing of the Hypothesis 2. Migrants' wisdom is found to have a significant influence toward migrants' competitiveness in Pekanbaru at the regression coefficient of $0.521, \mathrm{CR}$ of 0.628 and level of significance of 0.530 . Therefore, $\mathrm{H}_{\mathrm{o}}$ is accepted. The result of this study shows that wisdom has a positive yet insignificant influence toward migrants' competitiveness in Pekanbaru. follow.

The result of each indicator testing toward migrants' competitiveness is explained as

1. The influence of self-conceptualization toward migrants' competitiveness. The influence of self-conceptualization toward migrants' competitiveness shows value of $0.315, \mathrm{CR}$ at 3.643 and level of significance at 0.000 . This implies that selfconceptualization has a positive and significant influence on migrants' competitiveness.

2. The influence of awareness toward migrants' competitiveness. The influence of awareness on migrants' competitiveness shows value of $0.136, \mathrm{CR}$ at 3.918 and level of significance at 0.000 . It means that awareness has a positive and significant influence on migrants' competitiveness.

3. The influence of patience toward migrants' competitiveness. The influence of patience on migrants' competitiveness shows value of $0.257, \mathrm{CR}$ value at 5.051 and level of significance at 0.000 . Thus, patience shares a positive and significant influence on migrants' competitiveness.

4. The influence of cultural values toward migrants' competitiveness. The influecne of cultural values toward migrants' competitiveness shows value of $0.306, \mathrm{CR}$ at 4.030 and level of significance at 0.000 . It implies that cultural values have a positive and significant influecne on migrants' competitiveness. 
The result of this study also shows that self-conceptualization and cultural values appear to be the indicators that have strongest influence toward migrants' competitiveness in Pekanbaru.

\section{DISCUSSION OF RESULTS}

Based on the data of this study, the influence of each variable is explained as follow.

Current Migrants' Competitiveness in Pekanbaru. Migrants' competitiveness ( $\mathrm{Y}$ ) has been considered good at an average score of 1.8. It indicates that generally, migrants in Pekanbaru have adequate competitiveness and possess basic characteristics to reach good achievement, success or to reach their goals. A study conducted by Borja (2015) states that even though immigrants come with awful economic loss, they will get higher opportunities to develop themselves. Compared to the other indicators, productivity has the higher mean score. The productivity of migrants' competitiveness shows score 2.2 which shows that the results of their productivity or output remain strong in each job period. Quality is following with a score of 2.1, meaning that migrants' quality or achievement have been able to fulfill their daily necessity both primary needs and secondary needs. Adaptation also appears to be an indicator with high score at 1.9 which implies that the ability to adapt appears to be migrants' strength in facing difficult challenges. It can be seen from the length of their stay in which the longer they have stayed, the better their ability to adapt as experienced by migrants who had been living in Pekanbaru for 10 to 15 years. This result supports the finding of Borja, whose study shows that the within one or two decades after the arrival, migrants in America earn income closer to the average income even greater than the income of natives from the equal state of social and economy. In addition, only few research have shown that immigrants give negative effect toward natives' job opportunity. Generally, empirical studies show optimistic results related to immigrants' contribution for the economy of America.

In this study, there were two respondents who gave low scores for efficiency and innovation repectively at 1.5 and 1.3 . This finding shows that efficiency in the form of attitude for hybrid life in Pekanbaru is still weak. Innovation in the form of the agility to catch opprotunities seen from migrants' creativity is still weak since they tend to be passive. The productivity of migrants should be taken into account since it has high contribution to the nations' fiscal. In line with the result of a study conducted by Dutesmann and Frattini (2014) on the fiscal effects of immigration in UK shows that migrants in European countries tend to give positive contribution for England compared to migrants from other European countries. This positive contribution gives major benefits for the economy of Pekanbaru city.

The influence of skills toward migrants' competitiveness in Pekanbaru. Skills as a capital have a significant influence on migrants' competitiveness at a regression coefficient of $0.210, \mathrm{CR}$ at 1.957 , and level of significance at 0.05 which rejects the $\mathrm{H}_{0}$. The result of this study shows that skills have a positive and significant effect toward migrants' competitiveness in Pekanbaru.

Out of those four indicators, skills appear to have the strongest influence toward the competitiveness, followed by the experience. Meanwhile, knowledge and education are found to have weak influences. A study conducted by Hamberger (2009) highlights the importance of human resource as a precious capital which becomes a key factor of immigrants integration. Serious attempts should be made to improve the human resources capital to prevent immigrants from being burdens to a nation. It is also stated that human resource is often neglected as a capital when it is supposed to be well utilized. Nations should grow awareness that immigrants need be educated and well trained instead of being judged upon any stereotypes. Government should also make use of this human resource as a strong capital and take the most benefits from immigrants' background. In the other words, government need to see immigrants as a beneficial capital, not for merely a matter of formality, but government has to put it into practices.

The influence of wisdom capital toward migrants' competitiveness in Pekanbaru. Migrants' wisdom has a significant influence toward their competitiveness with a regression 
coefficient at $0.521, \mathrm{CR}$ at 0.628 , and level of significance at 0.530 . These values accept the Ho. The result of this study indicates that migrants' wisdom has a positive yet insignificant influence toward their competitiveness. This result goes in line with Coleman (1998) who found out that the culture where individuals grow up (usually referred as "social capital") can be seen as a human capital. He mentioned that social capital changes the job opportunity and significantly influences the attitudes, improve the human resources as the product of job market. In addition, he also conducted the study in the low-end class which result shows that integration has a strong influence for immigrants are required to adapt themselves into the new environment they are living in. Integration refers to the inclusion process and long-term acceptance of migrants upon the core institution, relationship and the status of the new society. Integration of migrants also refers to the process of learning new culture, receiving rights and access toward certain position and status, building up personal relationship with the target society, internalizing the feeling of belonged and identification of the immigrants society. Integration is also an interactive process between migrants and the natives in which natives have more power and prestige than the immigrants (Heckmann, 2005 as cited in King and Skeldon, 2010).

Hypothesis which states that this fact has an extern effect toward the accumulation of human capital has been widely used in sociology and social studies. It is also seen from the data that self-conceptualization and cultural values are hypotheses which have the strongest influence toward migrants' competitiveness in Pekanbaru.

\section{CONCLUSION AND SUGGESTIONS} follows.

Regarding to the result of this study as mentioned previously, conclusions are drawn as

Generally, migrants' competitiveness is considered good. Migrants own the basic characteristics to achieve good job achievement or success in reaching their goals. Two indicators obtained low scores; efficiency and innovation. It shows that migrants need to improve their attitude toward efficiency in the form of hybrid life style in Pekanbaru. Whilst, innovation refers to the ability to catch any opportunities which can be seen from their creativity in doing various jobs.

Skills of migrants have a significant influence toward their competitiveness at a regression coefficient of $0.201, \mathrm{CR}$ of 1.957 , and level of significance of 0.05 , which indicate that the Ho is rejected. The result of this study also shows that skills have a positive and significant influence toward migrants' competitiveness. Out of those four indicators, life skill appears to be the indicator with the strongest influence, followed by migrants' experience. Whereas, knowledge and educations are the indicators that have the lowest influence.

Migrants' wisdom also has a significant influence on their competitiveness at the regression coefficient at $0.521, \mathrm{CR}$ at 0.629 , and level of significance at 0.530 . therefore, Ho is accepted. Based on the result of this study, migrants' wisdom has a positive yet insignificant influence toward their competitiveness. This study also shows that selfconceptualization and cultural values are indicators that have the strongest influences toward migrants' competitiveness in Pekanbaru.

Moreover, based on the result of this study, some suggestions are made on how to improve migrants' competitiveness in Pekanbaru.

Migrants are suggested to improve their attitudes related to efficiency and innovation before coming to Pekanbaru in order to reach a success in the city.

The government of Pekanbaru is expected to be more selective in accepting migrants as permanent residents by adding higher requirement related to migrants' skills and experience in order to prevent the migrants from being jobless that eventually become big burden for the government.

Government of migrants' origin should give motivation to the migrants related to their goals of leaving the hometown. It is also important to enhance the cultural values understanding of migrants to help them adapting to the new circumstances well. 


\section{REFERENCES}

1. Borja, G.J. (2015). Immigration and Globalization: A Review Essay. Journal of Economic Literature, Vol. LIII (December). Harvard Kennedy School, USA.

2. Coleman, J.S. (1998). Social Capital in the Creation of Human Capital. Amer. J. Sociology, Supplement, 94, pp. S95-120.

3. Dinas Kependudukan dan Pencatatan Sipil. (2010). Catatan Sipil dalam Angka 2010. Pekanbaru: Dinas Kependudukan dan pencatatan Sipil.

4. Dustmann, Christian \& Frattini T. (2014). The Fiscal Effects of Immigration to The UK. The Economic Journal, USA.

5. Hamberger, A. (2009). Thematic Articles - Identity, Integration And Citizenship Immigrant Integration: Acculturation and Social Integration. Journal of Identity and Migration Studies, Volume 3, number 2. Cambridge University, UK.

6. Jones, Terry-Ann. (2009). Migration Theory in the Domestic Context: North-South Labor Movement in Brazil. Human Architecture: Journal of the Sociology of Self-Knowledge. Vol. 7, Issue 4, 5 - 14

7. King, R. \& Skeldon, R. (2010). Mind the Gap: Integrating Approaches to Internal and International Migration. Journal of Ethnic and Migration Studies, 36: 10, $1619-1646$, University of Sussex, UK.

8. Lee, E.S. (1995). Teori Migrasi. Translated by H. Daeng and reviewed by I.B. Mantra. Yogyakarta: Pusat Penelitian Kependudukan, UGM.

9. Lewis, M.A. (1954). Economic Development With Unlimited Supplies of Labour. UK: Manchester School.

10. Mattulada. (1994). Lingkungan Hidup Manusia. Jakarta: Pustaka Sinar Harapan.

11. Mantra, I.B. (2000). Demografi Umum. Yogyakarta: Pustaka Pelajar.

12. Mantra, I.B. (2003). Demografi Umum (Edisi 2). Yogyakarta: Pustaka Pelajar.

13. Preffer, J. (2002). Paradigma Baru Manajemen Sumber Daya Manusia. Yogyakarta: Amara Books.

14. Ranis, G. \& Fei, J.G. (1964). Development of the Labor Surplus Economy: Theory and Policy. Homewood, Illinois.

15. Suparmoko. (2008). Ekonomi Sumber Daya Alam dan Lingkungan Hidup. Yogyakarta: FE-UGM.

16. Todaro, M.P. (1996). Kajian Ekonomi Migrasi di Negara Berkembang: Telaah atas Beberapa Model. Translated by I.B. Mantra. Yogyakarta: Pusat Penelitian Kependudukan, UGM.

17. Todaro, M. (2002). Pembangunan Ekonomi di Dunia Ketiga. Translated by H. Munandar. Jakarta: Bumi Aksara. 